\title{
U.S. Geological Survey Archived Data Recovery in Texas, 2008-11
}

\section{Introduction}

The U.S. Geological Survey (USGS) collects and stores a wealth of environmental information and is the steward of many diverse datasets rich in unique information including historical observations, data, photographs, and descriptions of natural and human-caused changes in streamflow and stream channels, water quality, and groundwater. At the USGS Texas Water Science Center, water-related archived information dates back over 100 years. Until 2008, accessing any USGS Texas Water Science Center paper-form archived information required locating the information in Federal archives in Fort Worth, Texas.

As these paper-form records age, they can deteriorate or may otherwise become lost to future generations. In an effort to preserve the integrity of and improve access to these valuable resources, the USGS Texas Water Science Center initiated a data rescue and recovery project in 2008. A product of this effort was a prototype workflow, database, and Web user interface for the preservation and repurposing of valuable archived information.

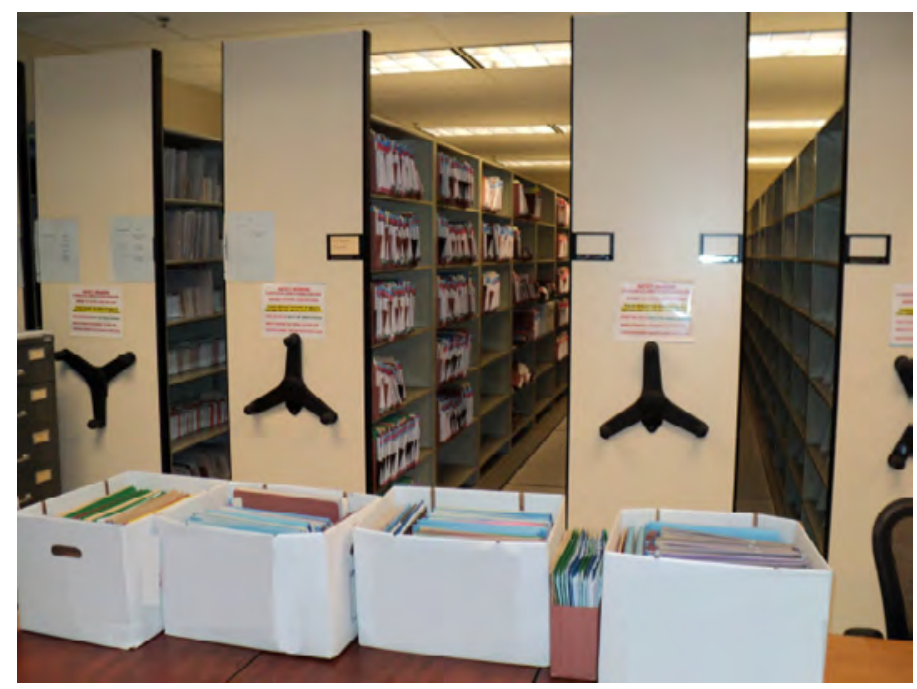

\section{For additional information, contact}

Director

USGS Texas Water Science Center

World Wide Web: http://txpub.usgs.gov/archives/

Email: gs-w-txpublic-info@usgs.gov

\section{Recovering Archived Information}

From 2008 to 2011, the following limited but highly valuable archived resources were digitized - indexed by common searchable themes such as USGS site number, specific date ranges, or document types - and made available online (http://txpub.usgs.gov/archives/):

- Approximately 6,000 photographs, measurements, reports, charts, maps, and other information from over 100 years of data collection at USGS station 08114000, Brazos River at Richmond, Texas.

- Approximately 3,600 sediment-related documents including data such as grain-size particle analyses at USGS stations across Texas.

- Approximately 400 aquifer test measurements, which show the aquifer response to either injection or withdrawal of known quantities of water.

- Forensic flood measurement data, documentation, and photographs from USGS stations across Texas.

- Documentation, data, and photographs from major Brazos River events.

- Searchable database that ties environmental data collection to Texas and USGS agency history.

\section{Summary}

The 2008-11 data rescue and recovery efforts by the U.S. Geological Survey (USGS) Texas Water Science Center resulted in an efficient workflow process, database, and Web user interface for scientists and citizens to access archived environmental information with practical applications. Much of this information is unique and has never been readily available to the public. The methods developed and lessons learned during this effort are now being applied to facilitate recovering archived information requested by USGS scientists, cooperators, and the general public.

\section{-Loren L. Wehmeyer and Brian D. Reece}

Publishing support provided by

Lafayette Publishing Service Center 